\title{
Relationship Between Self-confidence and Motivation: The Use of MMPI-2 in Medical Student
}

\author{
Irwan Syuhada $^{1 *}$, Artha Budi Susila Duarsa ${ }^{1}$, Ayu Anulus ${ }^{1}$ \\ ${ }^{1}$ Faculty of Medicine, Al-Azhar Islamic University \\ "Corresponding author. Email: pakirwansyuhada@gmail.com
}

\begin{abstract}
Self-confidence has gained growing prominence as one of the influential factors influencing academic performance. The study about self-confidence and motivation using the data from the Minnesota Multiphasic Personality Inventory2 (MMPI-2) test was rarely reported. This study aimed to examine the relationship between self-confidence and motivation among medical students. A cross-sectional study was conducted at Al-Azhar Islamic University, Mataram, West Nusa Tenggara. A total of 241 medical students participated in this study. The dependent variable was motivation. The independent variable was self-confidence. The data of motivation and self-confidence were obtained using the MMPI-2 test. The statistical analysis used Chi-square. Out of 241 medical students, 206 (85.48\%) students had the good motivation and $35(14.52 \%)$ had low motivation. 205 (85.06\%) students had good self-confidence and $36(14.94 \%)$ had low self-confidence. The results showed that motivation was associated with self-confidence $(p=0.001)$. The motivation is linked to the self-confidence among medical students at Al-Azhar Islamic University, Mataram, West Nusa Tenggara.
\end{abstract}

Keywords: Self-confidence, motivation, MMPI-2.

\section{INTRODUCTION}

Medical education is a complex education program. Medical students must learn about many competencies as stated in Competency Standards for Indonesian Doctors to become a professional doctor [1], including those who study in the Faculty of Medicine, Al-Azhar Islamic University.

Competencies in medical education programs are interrelated. Apart from having good academic abilities and skills, medical students must also acquire a good attitude that can be useful when they live in society. Therefore, to pass a medical education program, the student must have a good motivation and self-confidence level.

According to Sardiman in Maulida (2012), the term motivation is referred to the force within each individual that encourages the individual to do something. If an individual is well-motivated, he/she will do everything voluntarily, even without any reward [2].

Besides motivation, a medical student must have good self-confidence. Self-confidence is an individual's belief to achieve goals, desires, and hopes. This psychological aspect is crucial for medical students because they will serve as a professional doctor who will interact directly with the community/patients.

In order to determine the level of motivation and selfconfidence, the Minnesota Multiphasic Personality Inventory (MMPI) test has been widely used in many countries and has been translated into more than 100 languages. The Indonesian version of MMPI test was first developed by W. M. Roan, Yul Iskandar, and R. Salan in 1973. However, this edition was re-adapted due to less proper adaptation. This re-adaptation was then known as the MMPI Bahasa Indonesia II edition (MMPI-2). It was was developed by Syamsuddin et al. in 1982 [3].

Although the roles of motivation and self-confidence have been widely recognized to affect student learning and performance, there are only a few studies that have examined the relationship between these two constructs among college students, especially medical students. For that reason, this study was conducted to examine the relationship between self-confidence and motivation among medical students.

\section{SubJECTS AND Method}

\subsection{Study Design}

This study employed a cross-sectional design. The study was conducted at the Faculty of Medicine, AlAzhar Islamic University from June to August 2020. 


\subsection{Population and Sample}

The population in this study was all medical students in the Faculty of Medicine at the Al-Azhar Islamic University. Among them, 241 students were recruited for this study.

\subsection{Study Variables}

The variables in this study were motivation as the dependent variable and self-confidence as the independent variable. Self-confidence and motivation among students were obtained from the MPPI-2 test. The test covered twelve psychological items including selfconfidence and motivation items.

\subsection{Data Analysis}

As mentioned earlier, the MMPI-2 investigated the student's level of motivation and self-confidence. The test was conducted by the bioethics field of the Faculty of Medicine, Al-Azhar Islamic University. Various components were examined in this test. The data obtained from the MMPI-2 test were then taken and processed to conclude the psychological potential of FK-UNIZAR students including self-confidence and motivation. To do so, the data were analyzed using bivariate analysis (Chisquare).

\subsection{Research Ethics}

Research ethic included a consent form, anonymity, confidentiality, and ethical due diligence. Ethical clearance in this study was obtained from the Ethics Committee at the Faculty of Medicine, Al-Azhar Islamic University with the number: 026 / EC / FK-06 / UNIZAR / VIII / 2020.

\section{Results}

Table 1 shows data about motivation and selfconfidence among the medical students in the Faculty of Medicine, Al-Azhar Islamic University. Most of the students were reported to have good motivation $(85.48 \%)$ and only 35 students had moderate motivation (14.52\%). Similar findings were found in self-confidence data. Most of the students, i.e. 205 students, had good selfconfidence $(85.06 \%)$, while 36 students indicated moderate self-confidence (14.94\%).

Table 2 presents the results of the bivariate analysis. Of 241 medical students, 192 (79.7\%) students had good motivation and good self-confidence. Only 14 medical students $(5.8 \%)$ were revealed to have good motivation and moderate self-confidence. Following this, 13 medical students $(5.39 \%)$ recorded moderate motivation and good self-confidence. Finally, 22 medical students (9.12\%) indicated moderate motivation and self-confidence. Bivariate analysis of this showed that there was indeed a relationship between motivation and self-confidence among medical students and it was statistically significant (0.001)

Table 1. Characteristics of the Subjects

\begin{tabular}{|l|l|c|c|}
\hline \multicolumn{1}{|c|}{ No } & \multicolumn{1}{c|}{ Percent } \\
\hline \multicolumn{2}{|c|}{ Motivation } \\
\hline 1. & Good & 206 & 85.48 \\
\hline 2. & Moderate & 35 & 14.52 \\
\hline Self-Confidenceristics & & \\
\hline 1. & Good & 205 & 85.06 \\
\hline 2. & Moderate & 36 & 14.94 \\
\hline
\end{tabular}

Table 2. The results of Chi-square (bivariate) analysis

\begin{tabular}{|c|c|c|c|c|c|c|c|}
\hline \multirow{3}{*}{ Variables } & \multicolumn{4}{|c|}{ Self-Confidence } & \multirow{2}{*}{\multicolumn{2}{|c|}{ Total }} & \multirow{3}{*}{$\mathbf{p}$} \\
\hline & \multicolumn{2}{|c|}{ Good } & \multicolumn{2}{|c|}{ Moderate } & & & \\
\hline & $\mathbf{N}$ & $\%$ & $\mathbf{N}$ & $\%$ & $\mathbf{N}$ & $\%$ & \\
\hline $\begin{array}{l}\text { Motivation } \\
\text { Good }\end{array}$ & 192 & 79.7 & 14 & 5.8 & \multirow{2}{*}{241} & \multirow{2}{*}{100} & \multirow{2}{*}{0.001} \\
\hline Moderate & 13 & 5.39 & 22 & 9.12 & & & \\
\hline
\end{tabular}




\section{Discussion}

The Minnesota Multiphasic Personality Inventory (MMPI-2) test is a personality assessment instrument. The MMPI has been used widely in many countries. The test was first developed and arranged by Starke Rosencrans Hathaway and J. Charnley McKinley. It was then published by the University of Minnesota Press in 1943. After that, the MMPI test began to be restandardized in 1982 by James N. Butcher, W. Grant Dahlstrom, John R. Graham, Auke Tellegen, and Beverly Kaemmer. The re-standardization resulted in MMPI-2 which was the first revised edition since the MMPI test was published for the first time. The MMPI-2 test was first published in 1989 and was designed for adult participants aged above 18 years old [4]. In this study itself, the MMPI-2 used was in form of Indonesian language.

Results of the present study revealed that the students mostly had good motivation $(85.48 \%)$. Only a few students had moderate motivation $(14.52 \%)$. The same result was also found in the data regarding selfconfidence where most of the students had good selfconfidence $(85.06 \%)$ and a few had moderate selfconfidence (14.94\%). From the aforementioned data, it can be observed that motivation was related to selfconfidence, particularly in the context of medical students in the Faculty of Medicine, Al-Azhar Islamic University.

Self-confidence affects all aspects of a person's life, including medical students' life. Medical students must have a high degree of self-confidence because they will be dealing with patients and society after graduation. A doctor with a good self-confidence level can exude professional traits that may affect the patient's treatment and the taken decision. According to a recent study, selfconfidence is crucial in the health and medical fields [5].

Besides self-confidence, motivation also tends to be crucial for medical students because the medical education program is complex. The medical student must acquire all the competencies that are needed to become a professional doctor. A recent study shows that motivation can prevent the occurrence of psychological distress in medical students as well as their progression as lifelong learners [6].

The results of our study were supported by other studies which showed a relationship between selfconfidence and motivation. For instance, in 2019, Aisyah concluded that if students had a high level of selfconfidence, they also had a high level of motivation to excel [7]. Another study conducted by Wijaya (2018) also showed that there was a relationship between the level of self-confidence and motivation in badminton athletes statistically [8].

Self-confidence and motivation can also be related to other factors that come from outside an individual (socalled external factors, e.g. environment) and within the individual (so-called internal factors, such as anxiety) [8]. However, the present study only tested the relationship between motivation and self-confidence among medical students in the Faculty of Medicine, Al-Azhar Islamic University. Therefore, further research is needed to examine other factors that might be related to and associated with levels of motivation and self-confidence.

\section{CONCLUSION}

This study revealed similar results from other studies. In this study, we found a relationship between motivation and self-confidence among the medical students in the Faculty of Medicine, Al-Azhar Islamic University. However, this study has a limitation. This study only tested the relationship between motivation and selfconfidence among medical students in the Faculty of Medicine, Al-Azhar Islamic University. Therefore, further study is needed to examine other factors that might be related to and associated with levels of motivation and self-confidence.

\section{AUTHORS' CONTRIBUTIONS}

Irwan Syuhada designed the study problem and prepared the manuscript. Artha Budi Susila Duarsa enriched the background and discussion. Ayu Anulus analyzed the data and wrote the manuscript.

\section{ACKNOWLEDGMENTS}

All authors would like to thank the Faculty of Medicine, Al-Azhar Islamic University that provides facilities and fund to support this study.

\section{REFERENCES}

[1] KKI. Standar Kompetensi Kedokteran Indonesia. Jakarta: Konsil Kedokteran Indonesia; 2012.

[2] Deci EL, Ryan RM. Intrinsic Motivation. Corsini Encycl. Psychol., Hoboken, NJ, USA: John Wiley \& Sons, Inc.; 2010. doi:10.1002/9780470479216.corpsy0467

[3] Reed CJ. Brief History and Overview of the Minnesota Multiphasic Personality Inventory (MMPI) and MMPI-2 in Psychological Assessment and The Use Of These Test In Recent Research Studies In Indonesia 2006.

[4] Friedman AF, Bolinskey PK, Levak RW, Nichols DS. Psychological Assessment with the MMPI- 
2/MMPI-2-RF. 3rd (Third. New York: Routledge; 2015.

[5] Kukulu K, Korukcu O, Ozdemir Y, Bezci A, Calik C. Self-confidence, gender and academic achievement of undergraduate nursing students. J Psychiatr Ment Health Nurs 2013;20:330-5. doi:10.1111/j.1365-2850.2012.01924.x.

[6] Babenko O, Daniels LM, Ross S, White J, Oswald A. Medical Student Well - Being and Lifelong Learning: A Motivational Perspective. Educ Heal 2019;32:25-32. doi:10.4103/efh.EfH.

[7] Asiyah A, Walid A, Kusumah RGT. Pengaruh Rasa Percaya Diri Terhadap Motivasi Berprestasi Siswa pada Mata Pelajaran IPA. Sch J Pendidik Dan Kebud 2019;9:217-26. doi:10.24246/j.js.2019.v9.i3.p217-226.

[8] Wijaya IMK. Kecemasan, Percaya Diri, dan Motivasi Berprestasi Atlet UKM Bulutangkis. vol. 5. 2018. doi:10.23887/PENJAKORA.V5I1.14499. 